\title{
Commentary: Seek (the nodes) and you shall find (the nodes)
}

\author{
Waël C. Hanna, MDCM, MBA, FRCSC
}

\author{
From the Division of Thoracic Surgery, McMaster University, Hamilton, Ontario, Canada. \\ Disclosures: Author has nothing to disclose with regard to commercial support. \\ Received for publication Sept 8, 2019; accepted for publication Sept 10, 2019; available ahead of print Oct 23, \\ 2019. \\ Address for reprints: Waël C. Hanna, MDCM, MBA, FRCSC, St Joseph's Healthcare Hamilton, 50 Charlton Ave \\ E, Juravinski Tower, Suite T2105 F, Hamilton, Ontario, Canada L8N4A6 (E-mail: hannaw@mcmaster.ca). \\ J Thorac Cardiovasc Surg 2020;159:1097-8 \\ $0022-5223 / \$ 36.00$ \\ Copyright $(2019$ by The American Association for Thoracic Surgery \\ https://doi.org/10.1016/j.jtcvs.2019.09.022
}

The advent of low-dose computed tomography screening has redefined much of what we know about lung cancer, transforming it from a grim diagnosis in which treatment is futile to one in which long-term survival is possible. As surgeons, we saw our practice change to involve fewer extensive resections of large tumors and more targeted resections of small nodules. We have also replaced mediastinal lymph node dissections with more targeted lymph node sampling. ${ }^{1}$ As a result, we saw our specialty evolve into this new, and somewhat strange reality, in which we perform smaller and less morbid resections but achieve a better prognosis for early-stage lung cancer. The next question that naturally comes to mind-when dealing with very small nodules, do we even need to do any lymph node sampling at all?

In this issue of the Journal, Pani and colleagues ${ }^{2}$ address this question head on. Starting with the assumption that size and histology are the only determinants of the probability of lymph node spread, they perform a large retrospective database review looking for independent predictors of lymph metastasis. Their hypothesis was that nodules $<1 \mathrm{~cm}$ in diameter, and perhaps those with early adenocarcinoma spectrum histology, do not metastasize to regional lymph nodes. The paper does not specify whether patients received preoperative mediastinal staging or whether only clinical N0 patients were included in the analysis. However, the exclusion of all tumors $>2.0 \mathrm{~cm}$ in diameter allows one to assume that the prevalence of clinical lymph node disease in this population was very low. Not surprisingly, the incidence of node-positive disease in this low-risk population was $12.3 \%$, which is consistent with what has been previously reported about the rates of nodal upstaging in cN0 patients. $^{3}$ More importantly, the authors found that the incidence of nodal upstaging was not affected by either tumor size, or tumor histology.

The most resonant finding in this paper was that "significantly more lymph nodes were examined in the

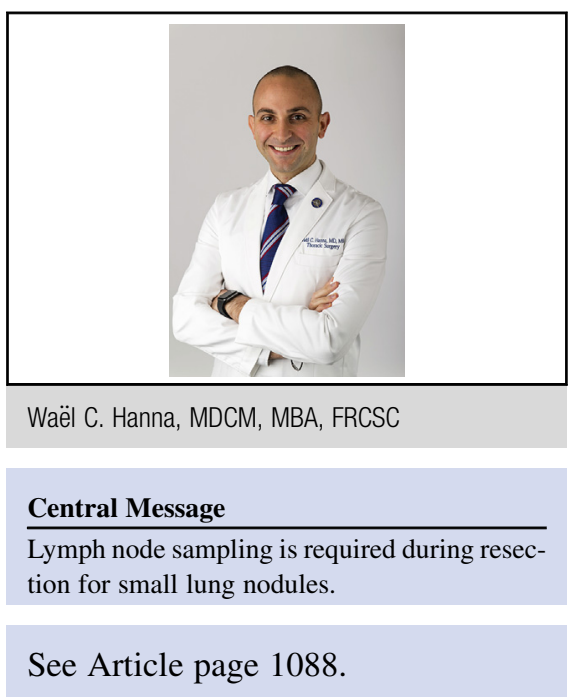

$\mathrm{LN}+$ group than the N0 group." The $\mathrm{LN}+$ group had a median of 13 nodes resected per case, compared with a median of 10 nodes in the NO group. This supports the longstanding "seek and you shall find" principle-the more extensive the lymph node sampling, the greater the chance of finding positive lymph nodes. Despite advances in lung cancer detection and treatment, we still don't know what we don't know about the patterns of lymph node spread. Significant work is being done to improve our understanding of both preoperative lymph node staging by ultrasound ${ }^{4}$ and intraoperative lymph node staging by sentinel node biopsy. ${ }^{5}$ Until then, the only principle that safely applies is "seek and you shall find," regardless of whether you are resecting a small nodule or a large tumor. From a patient perspective, many would agree that the morbidity of nodal dissection is much less meaningful than the morbidity of missed nodal disease.

\section{References}

1. Darling GE, Allen MS, Decker PA, Ballman K, Malthaner RA, Inculet RI, et al. Randomized trial of mediastinal lymph node sampling versus complete lymphadenectomy during pulmonary resection in the patient with $\mathrm{N} 0$ or N1 (less than hilar) non-small cell carcinoma: results of the American College of Surgery Oncology Group Z0030 trial. J Thorac Cardiovasc Surg. 2011; 141:662-70.

2. Pani E, Kennedy G, Zheng X, Ukert B, Jarrar D, Gaughan C, et al. Factors associated with nodal metastasis in 2-centimeter or less non-small cell lung cancer. J Thorac Cardiovasc Surg. 2020;159:1088-96.e1.

3. Bott MJ, Patel AP, Crabtree TD, Colditz GA, Kreisel D, Krupnick AS, et al Pathologic upstaging in patients undergoing resection for stage I non-small 
cell lung cancer: are there modifiable predictors? Ann Thorac Surg. 2015;100: 2048-53.

4. Hylton D, Huang J, Turner S, French D, Wen C, Masters J, et al. The Canada lymph node score: prospective development of a malignancy scoring system for lymph node assessment during staging endobronchial ultrasound evaluation of the mediastinum. Presented at: IASLC World Lung Cancer Conference; September 23, 2018; Toronto, Canada.

5. Hachey KJ, Colson YL. Current innovations in sentinel lymph node mapping for the staging and treatment of resectable lung cancer. Semin Thorac Cardiovasc Surg. 2014;26:201-9. 